\title{
APLIKASI KEMAHIRAN PEMIKIRAN SEJARAH DALAM MATA PELAJARAN SEJARAH DAN HUBUNGANNYA DENGAN MOTIVASI INTRINSIK: SATU KAJIAN KORELASI
}

\section{(HISTORICAL THINKING SKILLS APPLICATION ON HISTORY SUBJECT AND ITS RELATIONSHIP WITH INTRINSIC MOTIVATION: A CORRELATION STUDY)}

\author{
M. Kaviza*, Fauziah Abdul Rahim and Nurliyana Bukhari \\ School of Education and Modern Languages, UUM College of Arts and Sciences, \\ Universiti Utara Malaysia, 06010 Sintok, Kedah, Malaysia \\ *Corresponding author: kavizakaviza@yahoo.com
}

Published date: 31 March 2019

To cite this article: Kaviza, M., Fauziah Abdul Rahim, \& Nurliyana Bukhari. (2018). Aplikasi kemahiran pemikiran sejarah dalam mata pelajaran sejarah dan hubungannya dengan motivasi intrinsik: Satu kajian korelasi. Asia Pacific Journal of Educators and Educations, 33, 95-108. https://doi.org/10.21315/apjee2018.33.7

To link to this article: https://doi.org/10.21315/apjee2018.33.7

\begin{abstract}
Abstrak: Kajian ini bertujuan untuk menentukan hubungan antara kemahiran pemikiran terhadap motivasi intrinsik dalam mata pelajaran sejarah. Kajian ini berbentuk tinjauan secara korelasi yang melibatkan sampel kajian seramai 521 orang murid Tingkatan Empat di sebuah negeri di utara Semenanjung Malaysia yang dipilih melalui teknik persampelan rawak mudah. Instrumen kajian ini merupakan soal selidik yang telah diadaptasi dan disahkan oleh pakar pendidikan sejarah serta mempunyai nilai kebolehpercayaan yang baik. Dapatan kajian ini menunjukkan bahawa kemahiran pemikiran sejarah mempunyai hubungan linear positif yang tinggi secara signifikan terhadap motivasi intrinsik dalam kalangan murid. Tambahan pula, kemahiran membuat rasionalisasi, kemahiran memahami kronologi dan kemahiran meneroka bukti didapati menyumbang kepada motivasi intrinsik secara signifikan. Implikasi kajian ini mencadangkan bahawa kemahiran pemikiran sejarah perlu diterapkan secara menyeluruh dalam proses pengajaran dan pembelajaran sejarah kerana mempunyai kaitan dengan peningkatan motivasi intrinsik dalam kalangan murid.
\end{abstract}

Kata Kunci: kemahiran pemikiran sejarah, korelasi, mata pelajaran sejarah, motivasi intrinsik 


\begin{abstract}
This study aims to determine the relationship between historical thinking skills and intrinsic motivation in history subjects. This study involved 521 Form Four students from a state in northern Peninsular Malaysia using simple random sampling techniques. This research instrument is an adapted questionnaire which has been validated by content expert and has good reliability value. The findings of this study showed that the historical thinking skills have a significant high positive linear relationship with intrinsic motivation among students. Additionally, chronology skills, rationalisation skills and exploration of evidence have contributed significantly to intrinsic motivation. The implication of this study suggested that the historical thinking skills have to be implemented comprehensively because it is related to increase the intrinsic motivation among students.
\end{abstract}

Keywords: historical thinking skills, correlation, history subject, intrinsic motivation

\title{
PENGENALAN
}

Mata pelajaran sejarah merupakan salah satu mata pelajaran teras dalam kurikulum sejarah yang bermatlamat untuk melahirkan murid yang mengetahui fakta sejarah dalam sejarah Malaysia dan seluruh dunia, disamping merangsang pemikiran murid melalui proses pengajaran dan pembelajaran sejarah (Pusat Perkembangan Kurikulum (PPK), 2003, 2015). Proses pengajaran dan pembelajaran sejarah tidak seharusnya tertumpu kepada ledakan fakta semata-mata. Namun begitu, mata pelajaran sejarah perlulah berlandaskan kemahiran pemikiran sejarah iaitu situasi yang membolehkan murid dapat berfikir secara kritis, mampu membuat perkaitan di antara satu peristiwa dengan satu peristiwa yang lain, membuat interpretasi, mencari bukti, membuat pertimbangan dan ramalan serta imaginasi yang meletakkan murid pada kedudukan sebagai seorang sejarahwan (Bickford II \& Bickford, 2015; Cowgill II \& Waring, 2017). Maka, dalam usaha untuk melahirkan generasi yang dapat memenuhi matlamat dan aspirasi negara, proses pengajaran dan pembelajaran sejarah perlu menjurus kepada pemupukan kemahiran pemikiran sejarah dan peningkatan motivasi dalam kalangan murid (PPK, 2003, 2015) yang membolehkan murid memahami bagaimana ahli sejarah merekonstruksi sesuatu peristiwa lalu (Rosy, 2015; Twyman, McCleery \& Tindal, 2006; Siti Hawa, 2008). Terdapat lima konstruk dalam kemahiran pemikiran sejarah yang perlu dikuasai, dipupuk dan diperkembangkan dalam kalangan murid-murid (PPK, 2003, 2015):

1. Kemahiran memahami kronologi yang merujuk kepada urutan waktu dan peristiwa sejarah.

2. Kemahiran meneroka bukti yang melibatkan kemahiran mengenal pasti dan membuat kaji banding antara sumber primer dengan sumber sekunder untuk mendapatkan maklumat sejarah. 
3. Kemahiran membuat interpretasi yang membolehkan murid untuk membuat tafsiran terhadap sesuatu peristiwa dengan memberi ulasan berdasarkan bukti.

4. Kemahiran membuat imaginasi yang merupakan usaha untuk melibatkan murid dengan sesuatu situasi dalam peristiwa sejarah.

5. Kemahiran membuat rasionalisasi yang melibatkan penggunaan akal fikiran dan membuat pertimbangan yang wajar dalam menyelesaikan sesuatu masalah.

\section{PERNYATAAN MASALAH}

Murid-murid beranggapan bahawa mata pelajaran sejarah merupakan mata pelajaran yang tidak menarik dan bosan serta mereka tidak bermotivasi untuk belajar mata pelajaran tersebut (Ch'ng, 2005; Fadzillah, 2010; Ambika, Maskun, \& Suparman, 2017; Hazri, 2003; Omardin \& Yunus, 1996; Abdul Rahim, 2000; Eva, 2018). Tidak dinafikan bahawa faktor peningkatan dan penurunan motivasi intrinsik dalam kalangan murid yang mengambil mata pelajaran Sejarah dipengaruhi oleh pelbagai perkara, namun aplikasi kemahiran pemikiran sejarah yang merupakan komponen utama dalam kurikulum sejarah (PPK, 2003, 2015) didapati mempunyai kaitan secara tidak langsung terhadap peningkatan motivasi tersebut seperti yang dijelaskan dalam kajian-kajian terdahulu (Renuka, Norizan, \& Siti Hawa, 2014; Tally \& Goldenberg, 2005; Aidinopoulou \& Sampson, 2017). Aplikasi kemahiran pemikiran sejarah yang terhad semasa proses pengajaran dan pembelajaran sejarah di dalam kelas telah mewujudkan suasana pembelajaran yang hambar, tidak menarik dan tidak merangsang pemikiran kritis dan kreatif dalam kalangan murid (Izhab \& Muhamad Zaid, 2018; Muhamad Yazid, 2018; Anuar, Siti Haishah, \& Nur Atiqah, 2009) yang berkemungkinan menyebabkan murid gagal untuk menguasai isi kandungan mata pelajaran sejarah dengan lebih baik dan menjadi salah satu faktor penyumbang kepada kemerosotan motivasi untuk mempelajari sejarah (Wineburg, 2010; Bickford II \& Bickford, 2015). Satu keperluan dalam kajian ini adalah untuk mengenal pasti sama ada aplikasi kemahiran pemikiran sejarah dalam mata pelajaran sejarah mempengaruhi motivasi intrinsik dalam kalangan murid. 


\section{SOALAN KAJIAN}

Soalan kajian dalam kajian ini adalah seperti berikut:

1. Adakah terdapat hubungan yang signifikan antara kemahiran pemikiran sejarah terhadap motivasi intrinsik?

a. Adakah terdapat hubungan yang signifikan antara kemahiran memahami kronologi terhadap motivasi intrinsik?

b. Adakah terdapat hubungan yang signifikan antara kemahiran meneroka bukti terhadap motivasi intrinsik?

c. Adakah terdapat hubungan yang signifikan antara kemahiran membuat interpretasi terhadap motivasi intrinsik?

d. Adakah terdapat hubungan yang signifikan antara kemahiran membuat imaginasi terhadap motivasi intrinsik?

e. Adakah terdapat hubungan yang signifikan antara kemahiran membuat rasionalisasi terhadap motivasi intrinsik?

2. Adakah terdapat sumbangan pemboleh ubah peramal iaitu kemahiran memahami kronologi, kemahiran meneroka bukti, kemahiran membuat interpretasi, kemahiran membuat imaginasi dan kemahiran membuat rasionalisasi dalam kemahiran pemikiran sejarah terhadap motivasi intrinsik?

\section{METODOLOGI KAJIAN}

Kajian ini adalah berbentuk tinjauan secara korelasi (Creswell, 2014). Sampel kajian ini terdiri daripada 521 orang murid Tingkatan Empat di sebuah negeri di utara Semenanjung Malaysia melalui teknik persampelan rawak mudah. Jumlah sampel yang diperolehi dalam kajian ini adalah melebihi bilangan sampel yang diperlukan berdasarkan jadual penentuan saiz sampel kajian oleh Krejcie dan Morgan (1970). Instrumen kajian ini terdiri daripada soal selidik kemahiran pemikiran sejarah yang diadaptasi daripada kajian Rully Putri dan Abdul Razaq (2015), manakala soal selidik motivasi intrinsik pula telah diadaptasi daripada Intrinsic Motivation Inventory yang dibina oleh Deci dan Ryan (1985). Soal selidik motivasi intrinsik telah diterjemahkan daripada Bahasa Inggeris ke Bahasa Melayu dengan kaedah back to back translation (Neuman, 2000) oleh dua orang pakar dalam bidang bahasa. Kedua-dua soal selidik tersebut telah disahkan oleh pakar penilai dalam bidang pendidikan sejarah yang berpengalaman melebihi 
10 tahun serta mempunyai nilai kebolehpercayaan alfa Cronbach iaitu 0.94 bagi soal selidik kemahiran pemikiran sejarah dan 0.93 bagi soal selidik motivasi intrinsik yang dianggap baik oleh Nunnally (1978) dan diterima bagi tujuan kajian ini. Data kuantitatif dalam kajian ini telah dianalisis dengan menggunakan perisian IBM SPSS versi 24 secara statistik deskriptif dan statistik inferensi iaitu ujian korelasi Pearson dan Regresi Pelbagai. Interpretasi kekuatan korelasi dilakukan berdasarkan kajian Davies (1971) pada Jadual 1.

Jadual 1. Interpretasi kekuatan korelasi

\begin{tabular}{lc}
\hline Skor min & Tahap \\
\hline $0.70-1.00$ & Amat tinggi \\
$0.50-0.69$ & Tinggi \\
$0.30-0.49$ & Sederhana tiggi \\
$0.10-0.29$ & Rendah \\
$0.00-0.09$ & Diabaikan \\
\hline
\end{tabular}

Sumber: Adaptasi daripada Davies (1971).

\section{DAPATAN KAJIAN}

Bahagian ini membincangkan dapatan kajian bagi menjawab soalan 1 dan 2 yang telah dinyatakan.

\section{Soalan Kajian 1}

Pengkaji telah membentuk hipotesis nol (Ho) untuk diuji pada aras signifikan $(p=0.05)$ seperti berikut:

$\mathrm{H}_{\mathrm{o} 1}$ : Tidak terdapat hubungan yang signifikan antara kemahiran pemikiran sejarah terhadap motivasi intrinsik.

Berdasarkan Jadual 2, hasil dapatan kajian telah melaporkan bahawa nilai koefisien korelasi Pearson antara skor min kemahiran pemikiran sejarah $[r=0.75$, $p=0.00]$ terhadap motivasi intrinsik adalah signifikan iaitu hubungan linear yang positif yang amat tinggi. Maka, $\mathrm{H}_{\mathrm{ol}}$ berjaya ditolak. Justeru, terdapat hubungan antara skor min kemahiran pemikiran sejarah terhadap motivasi intrinsik dalam kalangan murid. Perkara ini menerangkan bahawa sekiranya aplikasi kemahiran pemikiran sejarah adalah tinggi, maka motivasi intrinsik dalam kalangan murid juga adalah tinggi. 
Jadual 2. Korelasi skor min kemahiran pemikiran sejarah terhadap motivasi intrinsik

\begin{tabular}{llc}
\hline & & Motivasi intrinsik \\
\hline Kemahiran pemikiran sejarah & Korelasi Pearson & $0.75^{* *}$ \\
& Sig. & 0.00 \\
& $\mathrm{~N}$ & 521 \\
\hline
\end{tabular}

Nota: ** Korelasi adalah signifikan pada tahap 0.05

\section{Soalan Kajian 1a}

Bagi menjawab soalan kajian 1a, pengkaji telah membentuk hipotesis nol (Ho) bagi diuji pada aras signifikan $(p=0.05)$ seperti berikut:

$\mathrm{H}_{\mathrm{ola}}$ : Tidak terdapat hubungan yang signifikan antara kemahiran memahami kronologi terhadap motivasi intrinsik.

Berdasarkan Jadual 3, hasil dapatan kajian telah melaporkan bahawa nilai koefisien korelasi Pearson antara skor min kemahiran memahami kronologi $[r=0.70$, $p=0.00]$ terhadap motivasi intrinsik adalah signifikan iaitu hubungan linear yang positif yang amat tinggi. Maka, $\mathrm{H}_{\mathrm{ola}}$ berjaya ditolak. Justeru, terdapat hubungan antara skor min kemahiran memahami kronologi terhadap motivasi intrinsik dalam kalangan murid. Perkara ini menerangkan bahawa sekiranya aplikasi kemahiran memahami kronologi adalah tinggi, maka motivasi intrinsik dalam kalangan murid juga adalah tinggi.

Jadual 3. Korelasi skor min kemahiran memahami kronologi terhadap motivasi intrinsik

\begin{tabular}{llc}
\hline & & Motivasi intrinsik \\
\hline Kemahiran memahami kronologi & Korelasi Pearson & $0.70^{* *}$ \\
& Sig. & 0.00 \\
& $\mathrm{~N}$ & 521 \\
\hline
\end{tabular}

Nota: $* *$ Korelasi adalah signifikan pada tahap 0.05

\section{Soalan Kajian 1b}

Bagi menjawab soalan kajian 1b, pengkaji telah membentuk hipotesis nol (Ho) bagi diuji pada aras kesignifikan $(p=0.05)$ seperti berikut:

$\mathrm{H}_{\mathrm{olb}}$ : Tidak terdapat hubungan yang signifikan antara kemahiran meneroka bukti terhadap motivasi intrinsik. 
Berdasarkan Jadual 4, hasil dapatan kajian telah melaporkan bahawa nilai koefisien korelasi Pearson antara skor min kemahiran meneroka bukti $[r=0.70, p=0.00]$ terhadap motivasi intrinsik adalah signifikan iaitu hubungan linear yang positif yang amat tinggi. Maka, $\mathrm{H}_{\mathrm{olb}}$ berjaya ditolak. Justeru, terdapat hubungan antara skor min kemahiran meneroka bukti terhadap motivasi intrinsik dalam kalangan murid. Perkara ini menerangkan bahawa sekiranya aplikasi kemahiran meneroka bukti adalah tinggi, maka motivasi intrinsik dalam kalangan murid juga adalah tinggi.

Jadual 4. Korelasi skor min kemahiran meneroka bukti terhadap motivasi intrinsik

\begin{tabular}{llc}
\hline & & Motivasi intrinsik \\
\hline Kemahiran meneroka bukti & Korelasi Pearson & $0.70^{* *}$ \\
& Sig. & 0.00 \\
& $\mathrm{~N}$ & 521 \\
\hline
\end{tabular}

Nota: ** Korelasi adalah signifikan pada tahap 0.05

\section{Soalan Kajian 1c}

Bagi menjawab soalan kajian 1c, maka pengkaji telah membentuk hipotesis nol (Ho) bagi diuji pada aras kesignifikan $(p=0.05)$ seperti berikut:

$\mathrm{H}_{\mathrm{olc}}$ : Tidak terdapat hubungan yang signifikan antara kemahiran membuat interpretasi terhadap motivasi intrinsik.

Berdasarkan Jadual 5, hasil dapatan kajian telah melaporkan bahawa nilai keofisien korelasi Pearson antara skor min kemahiran membuat interpretasi $[r=0.64$, $p=0.00]$ terhadap motivasi intrinsik adalah signifikan iaitu hubungan linear yang positif yang tinggi. Maka, $\mathrm{H}_{\mathrm{olc}}$ berjaya ditolak. Justeru, terdapat hubungan antara skor min kemahiran membuat interpretasi terhadap motivasi intrinsik dalam kalangan murid. Perkara ini menerangkan bahawa sekiranya aplikasi kemahiran membuat interpretasi adalah tinggi, maka motivasi intrinsik dalam kalangan murid juga adalah tinggi.

Jadual 5. Korelasi skor min kemahiran membuat interpretasi terhadap motivasi intrinsik

\begin{tabular}{llc}
\hline & & Motivasi intrinsik \\
\hline Kemahiran membuat interpretasi & Korelasi Pearson & $0.64 * *$ \\
& Sig. & 0.00 \\
& $\mathrm{~N}$ & 521 \\
\hline
\end{tabular}

Nota: ** Korelasi adalah signifikan pada tahap 0.05 


\section{Soalan Kajian 1d}

Bagi menjawab soalan kajian 1d, maka pengkaji telah membentuk hipotesis nol (Ho) bagi diuji pada aras signifikan $(p=0.05)$ seperti berikut:

$\mathrm{H}_{\text {old }}$ : Tidak terdapat hubungan yang signifikan antara kemahiran membuat imaginasi terhadap motivasi intrinsik.

Berdasarkan Jadual 6, hasil dapatan kajian telah melaporkan bahawa nilai koefisien korelasi Pearson antara skor min kemahiran membuat imaginasi $[r=0.63, p=0.00]$ terhadap motivasi intrinsik adalah signifikan iaitu hubungan linear yang positif yang tinggi. Maka, $\mathrm{H}_{\mathrm{old}}$ berjaya ditolak. Justeru, terdapat hubungan antara skor min kemahiran membuat imaginasi terhadap motivasi intrinsik dalam kalangan murid. Perkara ini menerangkan bahawa sekiranya aplikasi kemahiran membuat imaginasi adalah tinggi, maka motivasi intrinsik dalam kalangan murid juga adalah tinggi.

Jadual 7. Korelasi skor min kemahiran membuat imaginasi terhadap motivasi intrinsik

\begin{tabular}{llc}
\hline & & Motivasi intrinsik \\
\hline Kemahiran membuat imaginasi & Korelasi Pearson & $0.63^{* *}$ \\
& Sig. & 0.00 \\
& $\mathrm{~N}$ & 521 \\
\hline
\end{tabular}

Nota: ** Korelasi adalah signifikan pada tahap 0.05

\section{Soalan Kajian 1e}

Bagi menjawab soalan kajian 1e, maka pengkaji telah membentuk hipotesis nol (Ho) bagi diuji pada aras signifikan $(p=0.05)$ seperti berikut:

$\mathrm{H}_{\mathrm{ole}}$ : Tidak terdapat hubungan yang signifikan antara kemahiran membuat rasionalisasi terhadap motivasi intrinsik.

Berdasarkan Jadual 8, hasil dapatan kajian telah melaporkan bahawa nilai keofisien korelasi Pearson antara skor min kemahiran membuat rasionalisasi $[r=0.69$, $p=0.00]$ terhadap motivasi intrinsik adalah signifikan iaitu hubungan linear yang positif yang tinggi. Maka, $\mathrm{H}_{\mathrm{ole}}$ berjaya ditolak. Justeru, terdapat hubungan antara skor min kemahiran membuat rasionalisasi terhadap motivasi intrinsik dalam kalangan murid. Perkara ini menerangkan bahawa sekiranya aplikasi kemahiran membuat rasionalisasi adalah tinggi, maka motivasi intrinsik dalam kalangan murid juga adalah tinggi. 
Jadual 8. Korelasi skor min kemahiran membuat rasionalisasi terhadap motivasi intrinsik

\begin{tabular}{llc}
\hline & & Motivasi intrinsik \\
\hline Kemahiran membuat rasionalisasi & Korelasi Pearson & $0.69^{* *}$ \\
& Sig. & 0.00 \\
& $\mathrm{~N}$ & 521 \\
\hline
\end{tabular}

Nota: ** Korelasi adalah signifikan pada tahap 0.05

\section{Soalan Kajian 2}

Bagi menjawab soalan kajian 2, maka pengkaji telah membentuk hipotesis nol (Ho) bagi diuji pada aras kesignifkan $(p=0.05)$ seperti berikut:

$\mathrm{H}_{02}$ : Tidak terdapat sumbangan yang signifikan antara pemboleh ubah peramal iaitu kemahiran memahami kronologi, kemahiran meneroka bukti, kemahiran membuat interpretasi, kemahiran membuat imaginasi dan kemahiran membuat rasionalisasi dalam kemahiran pemikiran sejarah terhadap motivasi intrinsik.

Berdasarkan Jadual 9 dan Jadual 10, pemboleh ubah peramal telah menyumbang secara signifikan terhadap motivasi intrinsik $[F(5,515)=138.01, p=0.00]$ dan menyumbang sebanyak $57 \%$ varians terhadap motivasi intrinsik $\left(r^{2}=0.57\right)$. Sungguhpun begitu, hanya tiga pemboleh ubah peramal sahaja yang memberi sumbangan secara signifikan terhadap motivasi intrinsik berdasarkan nilai pemberat regresi piawai $(\beta)$ iaitu pemboleh ubah kemahiran membuat rasionalisasi, yang merupakan peramal yang tertinggi $(\beta=0.28, t=5.05, p=0.00)$, diikuti dengan pemboleh ubah kemahiran memahami kronologi $(\beta=0.27, t=5.30, p=0.00)$ dan pemboleh ubah kemahiran meneroka bukti $(\beta=0.26, t=4.33, p=0.00)$. Namun begitu, dua pemboleh ubah peramal yang lain iaitu pemboleh ubah kemahiran membuat interpretasi $(\beta=0.01, t=0.19, p=0.85)$ dan pemboleh ubah kemahiran membuat imaginasi $(\beta=0.01, t=0.17, p=0.87)$ tidak memberikan sumbangan yang signifikan terhadap motivasi intrinsik. Maka,pemboleh ubah kemahiran membuat kronologi, kemahiran meneroka bukti dan kemahiran membuat rasionalisasi merupakan pemboleh ubah peramal kepada motivasi intrinsik. Perkara ini menunjukkan bahawa nilai $(\beta)$ bagi setiap unit peningkatan dalam pemboleh ubah tidak bersandar adalah diikuti dengan setiap unit peningkatan dalam pemboleh ubah bersandar. Oleh itu, nilai pekali menunjukkan bahawa terdapat hubungan linear bagi model dengan persamaan garis lurus bagi motivasi intrinsik dengan pemboleh ubah peramal adalah seperti berikut: 
M. Kaviza et al.

$$
\begin{gathered}
\mathrm{Y}=\mathrm{A}+\mathrm{B}_{1 \mathrm{X} 1}+\mathrm{B}_{2 \mathrm{X} 2}+\mathrm{B}_{3 \mathrm{X} 3}+\mathrm{e} \\
{\left[\mathrm{Y}=1.51+0.22_{\mathrm{X} 1}+0.20_{\mathrm{X} 2}+0.22_{\mathrm{X} 3}+0.11\right]}
\end{gathered}
$$

di mana

$\mathrm{Y}=$ motivasi intrinsik; $\mathrm{A}=$ pemalar; $\mathrm{B}_{1}, \mathrm{~B}_{2}, \mathrm{~B}_{3}=$ pekali; $\mathrm{x} 1=$ kemahiran memahami kronologi; ${ }_{\mathrm{x} 2}=$ kemahiran meneroka bukti, ${ }_{\mathrm{x} 3}=$ kemahiran membuat rasionalisasi; e = ralat kajian.

Jadual 9. Analisis varians regresi pelbagai

\begin{tabular}{lcrccc}
\hline Pemboleh ubah & Jumlah kuasa dua & \multicolumn{1}{c}{ df } & Min kuasa dua & $F$ & Sig. \\
\hline Regresi & 250.22 & 5 & 50.04 & 138.09 & 0.00 \\
Reja & 186.64 & 515 & 0.36 & & \\
Jumlah & 436.85 & 520 & & & \\
\hline
\end{tabular}

Jadual 10. Analisis regresi pelbagai bagi motivasi intrinsik dengan pemboleh ubah peramal

\begin{tabular}{lccccc}
\hline Pemboleh ubah & Pekali tidak piawai $(B)$ & Ralat pekali & Pekali piawai $(\beta)$ & $t$ & Sig. \\
\hline Pemalar & 1.51 & 0.11 & & 13.81 & 0.00 \\
Kronologi & 0.22 & 0.41 & 0.27 & 5.30 & 0.00 \\
Bukti & 0.20 & 0.46 & 0.26 & 4.33 & 0.00 \\
Interpretasi & 0.01 & 0.41 & 0.01 & 0.19 & 0.85 \\
Imaginasi & 0.01 & 0.40 & 0.01 & 0.17 & 0.87 \\
Rasionalisasi & 0.22 & 0.44 & 0.28 & 5.05 & 0.00 \\
\hline
\end{tabular}

\section{PERBINCANGAN KAJIAN}

Hasil dapatan kajian ini menunjukkan bahawa aplikasi kemahiran pemikiran sejarah merupakan faktor penting dalam menentukan peningkatan motivasi intrinsik dalam kalangan murid. Hal ini adalah disebabkan objektif kurikulum sejarah yang telah menggariskan kepentingan elemen pemikiran dan motivasi dalam kalangan murid (PPK, 2003, 2015). Sungguhpun begitu, faktor yang dikaji tidak dihadkan kepada kemahiran pemikiran sejarah sahaja, malah ianya perlu ditentukan dengan pelbagai faktor yang lain dalam kurikulum sejarah agar suatu gambaran yang lebih luas dan tepat berkaitan peningkatan motivasi intrinsik dapat dilakukan. Dapatan kajian ini adalah seiring dengan kajian Aktin (2016), Groot-Reuvekamp dan Ros (2017) dan Cowgill II dan Waring (2017) yang mendapati bahawa aplikasi 
kemahiran pemikiran sejarah dalam proses pengajaran dan pembelajaran sejarah dapat mempengaruhi peningkatan motivasi mempelajari mata pelajaran sejarah yang lebih baik dalam kalangan murid. Tambahan pula, kesimpulan yang sama juga dapat dibuat terhadap kelima-lima konstruk dalam kemahiran pemikiran sejarah iaitu kemahiran memahami kronologi, kemahiran meneroka bukti, kemahiran membuat interpretasi, kemahiran membuat imaginasi dan kemahiran membuat rasionalisasi yang mempunyai kaitan dengan peningkatan motivasi intrinsik dalam kalangan murid secara langsung mahupun secara tidak langsung. Dapatan kajian ini juga didapati bertepatan dengan dapatan kajian Lee (2013), Wineburg (1991), Sharifah NorPuteh, Nooreiny dan Elisabeth (2010), Renuka et al. (2014) dan Young (2012) yang menjelaskan bahawa proses pengajaran dan pembelajaran sejarah yang berteraskan kepada aplikasi kemahiran pemikiran sejarah menjadi faktor yang menyumbang kepada peningkatan prestasi dan minat, serta perubahan sikap yang positif. Sehubungan dengan itu, konstruk kemahiran memahami kronologi, kemahiran meneroka bukti dan kemahiran membuat rasionalisasi yang didapati menjadi faktor penyumbang kepada peningkatan motivasi intrinsik dalam kalangan murid adalah selari dengan kajian Greene, Bolick dan Robertson (2010) dan kajian Abdul Razaq, Ahmad Ali, Mohd Mahzan dan Fadzillah (2015), Nurul Hafizah, Nurul Suzaina dan Nur Nadia (2018) serta kajian Abdul Razaq (2010) yang menjelaskan bahawa aplikasi kemahiran pemikiran sejarah dan kecerdasan pelbagai dalam amalan pengajaran dan pembelajaran sejarah di dalam kelas adalah berupaya untuk meningkatkan motivasi secara lebih menyeluruh dalam kalangan murid. Hal ini demikian kerana proses pengajaran dan pembelajaran sejarah yang lebih bermakna melalui aktiviti pembelajaran bersifat hand-on dan mind-on dalam aplikasi kemahiran pemikiran sejarah dapat membentuk daya intelek yang tinggi dan meningkatkan motivasi dalaman yang baik dalam kalangan murid (Albreeht \& Karabenick, 2018; Straaten, Wilschut, \& Oostdam, 2016; Roth \& Hsu, 2008; Subadrah, Rajeswari, \& Najeemah, 2011).

\section{KESIMPULAN}

Kepentingan aplikasi kemahiran pemikiran sejarah dan motivasi intrinsik dalam kalangan murid tidak dapat diabaikan lagi dalam konteks kurikulum sejarah kerana murid merupakan aset penting dalam pembangunan negara pada masa akan datang. Kajian ini berjaya mengenal pasti bahawa aplikasi kemahiran pemikiran sejarah mempengaruhi peningkatan motivasi intrinsik dalam kalangan murid yang mengambil mata pelajaran sejarah di sekolah menengah harian secara langsung mahupun secara tidak langsung. Implikasi kajian ini diharapkan dapat dijadikan bahan rujukan kepada semua pihak yang terlibat dengan menyediakan maklumat bahawa aplikasi kemahiran pemikiran sejarah dengan lebih baik dalam 
proses pengajaran dan pembelajaran sejarah didapati mempengaruhi peningkatan motivasi intrinsik dalam diri murid bagi membentuk jati diri dan nilai patriotisme terhadap negara. Malahan, hubungan linear positif yang tinggi tersebut antara kemahiran pemikiran sejarah terhadap motivasi intrinsik membolehkan semua pihak berganding bahu untuk memastikan objektif kurikulum sejarah dapat dicapai.

\section{RUJUKAN/REFERENCES}

Abdul Rahim Abdul Rashid. (2000). Model dan pendekatan pengajaran sejarah KBSM. Kuala Lumpur: Dewan Bahasa dan Pustaka.

Abdul Razaq Ahmad. (2010). The acquisition of conceptual understanding of historical thinking in the context of multi-ethnic students in Malaysia. Historia: Jurnal Pendidik dan Peneliti Sejarah, 10(2), 108-119.

Abdul Razaq Ahmad, Ahmad Ali Seman, Mohd Mahzan Awang, \& Fadzillah Sulaiman. (2015). Application of Multiple Inteligence Theory to increase student motivation in learning history. Asian Culture and History, 7(1), 210-219.

Aidinopoulou, V., \& Sampson, D. (2017). An action research study from implementing the flipped classroom model in primary school history teaching and learning. Educational Technology \& Society, 20(1), 237-247.

Aktin, K. (2016). A semiotic analysis on the utilization of historical thinking skills in preschool period. Academic Journals, 11, 1335-1366.

Albreeht, J. R., \& Karabenick, S. A. (2018). Relevance for learning and motivation in education. The Journal of Experimental Education, 86(1), 1-10. https://doi.org/1 $0.1080 / 00220973.2017 .1380593$

Ambika Luhitadati, Maskun, \& Suparman Arif. (2017). Hubungan motivasi berprestasi dengan hasil belajar siswa pada mata pelajaran sejarah. Jurnal Pendidikan dan Penelitian Sejarah, 5(8), 1-12.

Anuar Ahmad, Siti Haishah Abdul Rahim, \& Nur Atiqah T. Abdullah. (2009). Tahap keupayaan pengajaran guru sejarah dan hubungannya dengan pencapaian murid berprestasi rendah. Jurnal Pendidikan Malaysia, 34(1), 53-66.

Bickford II, J. H., \& Bickford, M. S. (2015). Historical thinking, reading and writing about world's newest nation, South Sudan. Social Studies Research and Practice, 10(2), $111-123$.

Ch'ng, S. H. (2005). Penggunaan ICT untuk memperkembangkan pengetahuan, kreativiti dan minat terhadap mata pelajaran sejarah Tingkatan Empat. Unpublished Masters thesis, Universiti Malaya.

Cohen, J. (2013). Statistical power analysis for the behavioral sciences (2nd ed.). Hoboken: Taylor \& Francis. https://doi.org/10.4324/9780203771587

Cowgill II, D. A., \& Waring, S. M. (2017). Historical thinking: An evaluation of student and teacher ability to analyze sources. Journal of Social Studies Education Research, 8(1), 115-145. 
Creswell, J. W. (2014). Educational research: Planning, conducting and evaluating quantitative and qualitative research (4th ed.). Upper Saddle River, NJ: Pearson International.

Davies, J. A. (1971). Elementary survey analysis. New Jersey: Prentice Hall.

Deci, E. L., \& Ryan, R. M. (1985). Intrinsic motivation and self-determination of human behavior. New York: Plenum. https://doi.org/10.1007/978-1-4899-2271-7

Eva Budi Effila. (2018). Upaya meningkatkan motivasi belajar sejarah siswa XII IPA1 SMA Negeri 1 Pasir Penyu melalui penggunaan media film dokumenter. Jurnal Pendidikan Tambusai, 2(4), 606-618.

Fadzilah Sulaiman. (2010). Keberkesanan aplikasi teori kecerdasan pelbagai untuk meningkatkan pencapaian dan motivasi pelajar berpencapaian akademik rendah dalam mata pelajaran sejarah. Unpublished Masters thesis, Universiti Kebangsaan Malaysia.

Greene, J. A., Bolick, C. M., \& Robertson, J. (2010). Fostering historical knowledge and historical thinking skills using hypermedia learning environments: The role of self-regulated learning. Journal Computers \& Education, 54(1), 230-243. https:// doi.org/10.1016/j.compedu.2009.08.006

Groot-Reuvekamp, M. D., \& Ros, A. (2017). Improving elementary school students understanding of historical time: Effects of teaching with "Timewise". Theory \& Research in Social Education, 46(1), 1-33.

Hazri Jamil. (2003). Teknik mengajar Sejarah. Pahang: PTS Publications \& Distributors.

Izhab Ismail, \& Muhamad Zaid Ismail. (2018). Hubungan kemahiran pemikiran sejarah dengan amalan guru dalam proses pengajaran dan pembelajaran sejarah. Paper presented at Prosiding Seminar Kebangsaan Majlis Dekan Pendidikan Universiti Awam 2018, Universiti Sultan Zainal Abidin, 7-8 November, 303-320. Retrieved from https:/www.unisza.edu.my/medc2018/images/303-320_IZHAB_ ISMAIL_MUHAMAD_ZAID_IBRAHIM.pdf

Krejcie, V. R., \& Morgan, W. D. (1970). Determining sample size for research activities, educational and psychological measurement. Duluth, MN: University of Minnesota.

Lee, M. (2013). Promoting historical thinking using the explicit reasoning text. The Journal of Social Studies Research, 37, 33-45. https://doi.org/10.1016/j.jssr.2012.12.003

Muhamad Yazid Khalil. (2018). Tahap pengetahuan guru sejarah sekolah rendah dalam kemahiran pemikiran Sejarah. Paper presented at National Innovation and Invention Competition through Exhibition (I-Complex), 20-23 March, Politeknik Sultan Abdul Halim Muadzam Shah, Kedah.

Neuman, W. L. (2000). Social research methods: Qualitative and quantitative approaches (4th ed.). Boston, MA: Allyn and Bacon.

Nunnally, J. C. (1978). Psychometrie theory (2nd ed.). New York: McGraw Hill.

Nurul Hafizah Ma'rof, Nurul Suzaina Joli, \& Nur Nadia Lani. (2018). Tinjauan kecenderungan pelajar pintar, cerdas dan berbakat dalam subjek Sejarah Malaysia. International Journal of Education, Psychology and Counseling, 3(20), 51-64.

Omardin Haji Ashaari, \& Yunus Muhammad. (1996). Kaedah pengajaran Sejarah. Kuala Lumpur: Utusan Publication and Distributor Sdn Bhd. 
Pusat Perkembangan Kurikulum. (2003). Huraian sukatan pelajaran Sejarah Tingkatan Empat. Kuala Lumpur: Kementerian Pendidikan Malaysia.

Pusat Perkembangan Kurikulum. (2015). Dokumen standard dan pentaksiran mata pelajaran Sejarah Tingkatan Satu. Putrajaya: Kementerian Pendidikan Malaysia.

Renuka Ramakrishnan, Norizan Esa \& Siti Hawa Abdullah. (2014). Kesan penggunaan sumber sejarah digital terhadap kemahiran pemikiran sejarah. Paper presented at The 23rd International Conference of Historians of Asia 2014 (IAHA), 23-27 August, TH Hotel and Convention Centre, Alor Setar, Kedah.

Rosy Talin. (2015). Historical thinking skills: The forgotten skills? International Journal of Learning and Teaching, 7(1), 15-23. https://doi.org/10.18844/ijlt.v7i1.3

Roth, W. M., \& Hsu, P. L. (2008). Interest and motivation: A cultural-historical and discursive psychological approach. In J. E. Larsons (ed.), Cognition and learning, individual differences and motivation (pp. 1-32). Nova: Science Publisher.

Rully Putri Nirmala Puji, \& Abdul Razaq Ahmad. (2015). Gaya belajar dan kemahiran pemikiran sejarah dalam pembelajaran Sejarah di peringkat universitas. Edusentris: Jurnal Ilmu Pendidikan dan Pengajaran, 2(3), 253-263.

Sharifah NorPuteh, Nooreiny Maarul, \& Elisabeth Tak. (2010). Students' perception of the teaching of historical thinking skills. Pertanika Journal Social Science \& Humanities, 18(S), 87-95.

Siti Hawa Abdullah. (2008). Takrif dan ciri-ciri pemikiran Sejarah. Pendidikan Sejarah, 9(1), 98-106.

Straaten, D. V., Wilschut, A., \& Oostdam, R. (2016). Making history relevant to students by connecting past, present and future: A framework for research. Journal of Curriculum Studies, 48(4), 479-502.

Subadrah Nair, Rajeswari P. Sinnasamy, \& Najeemah Mohd Yusof. (Julai, 2011). Patriotisme dalam kalangan murid Tingkatan Empat dan hubungannya dengan minat terhadap Sejarah. Seminar Pendidikan Sejarah dan Geografi, Sekolah Pendidikan dan Pembangunan Sosial, Universiti Malaysia Sabah.

Tally, B., \& Goldenberg, L. B. (2005). Fostering historical thinking with digitized primary resources. Journal of Research on Technology in Education, 38(1), 1-21. https:// doi.org/10.1080/15391523.2005.10782447

Twyman, T., McCleery, J., \& Tindal, G. (2006). Using concepts to frame history content. The Journal of Experimental Education, 74(4), 331-349. https://doi.org/10.3200/ JEXE.74.4.329-350

Wineburg, S. (1991). Historical problem solving: A study of the cognitive processes used in the evaluation of documentary and pictorial evidence. Journal of Educational Psychology, 83, 73-87. https://doi.org/10.1037/0022-0663.83.1.73

Wineburg, S. (2010). Historical thinking and other unnatural acts. Kappan Classic, 92(4), 81-94. https://doi.org/10.1177/003172171009200420

Young, S. (2012). Understanding history through the visual images in historical fiction. Language Art, 89(6), 379-395. 